\title{
Student Library Habits
}

BY JOHN WEATHERFORD

TN THE PAST THIRTY YEARS a number of 1 statistical studies have appeared pointing to various characteristics of the library habits of college students. ${ }^{1}$ Generally speaking, each study has represented a different campus. For several reasons, few comparisons between universities are possible. For one thing, the units of measure have not been comparable: here one counts charges, there one counts unduplicated titles; some count graduates, some only freshmen; and so on.

The statistical studies have grown in sophistication since the 1930's. At first they seemed concerned with the mere gross quantity of a student's reading. Increasingly, the studies have tended to compare various kinds of books or of library service with various kinds of students. The most recent and advanced of

1 Harvie Branscomb, Teaching with Books (Chicago: ALA, 1940) 233 pp. Dr. Branscomb digests his own study of two universities and six other studies of the 1930 's, all concerned with the per capita borrowing. Douglas Waples et. al. The Library (vol. IV of The Evaluation of Higher Institutions. Chicago: University of Chicago Press, 1936), pp. 39-60. Waples used regular two-weeks loan records over 70 - to 100 -day periods to two-weeks loan records over 70 - to 100 -day periods to analyze the types of books borrowed and to make per
capita comparisons among 233 universities and colleges. Although he made no comparisons of these data with student characteristics, he hoped that it would be done and suggested for this purpose using borrowers' cards on which each loan is entered for later comparison with whatever student characteristics are looked up in the whatever student characteristics are looked up in the
university records. This is the method employed, as we shall see, by Julia Thorne.

Floyd Reves et al., The Liberal Arts College (Chicago: University of Chicago Press, 1932), 715 pp., had conducted similar studies of thirty-five Methodist colleges, again concerned with per capita borrowing rather than correlations with student qualities.

Frances G. Kemp analyzed the non-reserve books borrowed by freshmen at Sarah Lawrence College in 1939 1940. She kept a separate charge record for the 125 girls comprising the class. Frances G. Kemp, "Fresh. man Reading in a Progressive College" (M. S. Thesis, Columbia University, 1941)

Julia Thorne correlated the kind of books borrowed with their borrowers' intelligence scores and reading in terests, by making a card for each borrower, on which each loan was entered when made. The subjects were the 181 students at Plymouth Teachers College in 1941 1942. Julia Thorne, "An Analysis of Intelligence Rating and Reading Interests" (M. S. Thesis, Columbia University, 1946).

In George Donald Smith, "The Nature of Student Reading" (Ph.D. Dissertation, University of Chicago, 1946), the loan slips of the freshman class of the University of Chicago were kept so as to distinguish among indispensable, optional, and other titles. The names of
Mr. Weatherford is Assistant Librarian, Miami University, Oxford, Ohio.

these has been Patricia Knapp's study of Knox College in her College Teaching and the College Library, already cited. Investigations of this calibre are beyond the reach of ordinary library circulation records. These correlations are possible only if a student and his borrowing are linked together in the record. A call-slip charging system, such as that used at Knox, furnishes this link, for the student and his book are tied together on a single slip. Cut the paper in two, and there can be no correlations at all; leave it whole and there can be dozens.

Yet, as far as method is concerned, the work has only begun with the call slip. Usually we know from it only the student's name and address; some call slips ask him for his class, or whether he is an undergraduate. Any other traits needed for our statistical comparisons have to be looked up somewhere, such as in the registrar's office. People reading the Knox

the students were then looked up to make comparisons with grades and with various aptitude, maturity, trait, and other scores in tests given by the university.

Ann M. Todd based her study on all non-reserve circulation records during October-December 1942, using a special call slip for that period, on which the student registered whether the transaction was for class work or was independent, what his class and school were, and whether he was employed. Then in January 1943 those who had borrowed books during that period were sent postal card questionnaires concerning their employment and other extra-curricular drains on their time; 54 per cent of the post cards were returned. Ann M. Todd, Undergraduate Reading at the University of Missouri (M. A. Thesis, University of Chicago, 1948). Patricia B. Knapp, College Teaching and the College
Library (A.C.R.L. Monograph No. 23. Chicago: ALA 1959) covers many aspects of that subject. The part that concerns us here is, of course, her analysis of student library use. This was based on all circulation records for the spring quarter of 1954 at Knox College. These consisted of a special call slip on which the student entered not only his name and the identity of the book, but the course for which the book was borrowed book, but the course for which the book was borrowed
(or whether it was for leisure reading). All other information-that is, the basis for correlation with student characteristics-was looked up in university records under each student's name. The student body totalled 738 at that time. 


\section{Library Use Survey \\ FEBRUARY 1959}

You are one of a sample group of Miami students ${ }^{2}$ chosen for a study of undergraduate use of the university libraries. Try to answer this questionnaire to the best of your memory. If you cannot remember at all, just say so.

Your Name Will Not Appear Anywhere on This Questionnaire, So You May ANSWER FrankLy.

1. Circle sex: $M \quad F$

2. Circle the class you were in last semester: F SO J SE

3. What grade point average did you earn last semester?

4. What was your major last semester?

5. How many different books did you borrow from the university libraries last semester?

6. How many of these were on reserve in the basement?

7. How many of the books you borrowed were specifically required reading for one of your courses?

8. How many were connected with your major?

9. How many were for recreation only?

10. How many came from each of the following departmental libraries?

— architecture
- biology
- chemistry
— geology

- physics

IML

children's room in main library building

other (specify):

11. How many of the books you charged out did you read more than half through?

12. How many of them did you not read at all?

study must have been impressed with the amount of work it obviously required. Some of the other studies have involved similar expenditures of labor and time.

This expenditure would become a real financial problem in any attempt to conduct a uniform and detailed study of several universities. Even if there were no thought of a concerted study, the larger universities would find such an effort forbidding. Knox students numbered
738. What of a university with ten or thirty times that number? Another difficulty in applying these methods broadly is that they have required a particular kind of charging system. Libraries with different systems could not be surveyed in this way.

2 Undergraduates were chosen according to positions their names occupied on the pages of the student directory. The experimental sample ( 165 out of 5542 undergraduates) though large enough for some purposes was too small for others, leaving us with less information than might have been wrung from the questionnaire if the sample had been larger or deliberately weighted to make it still more representative. 
Finally, there is a growing tendency to put books out on open shelves-open reserves, divisional reading rooms, undergraduate libraries, open stacks, and so on-so that a growing portion of student use of library books will not be reflected in the circulation slips.

It was to meet these problems that an experimental survey was conducted at Miami University in February 1959. It was hoped not only to observe some undergraduate student library habits, but also to develop a method that could be economically and uniformly applied to many universities. There were two departures from previous practice. One was to use a questionnaire instead of charging records. The other was to study a sample instead of the entire student body. Because the survey depended on memory, it was carried out immediately at the beginning of the second semester. ${ }^{3}$ Although the undergraduates were picked at random, the sample necessarily excluded those who had graduated, failed, or otherwise disappeared by the end of the semester.

From this questionnaire, obviously, many tabulations can be easily made, covering most of the areas of former studies and some new ones as well. Here, for example, are a few of the local re-

3 Only one or two students failed to answer for fault of memory. It seems clear that the reliability of the students' memories is high when few books are concerned and decreases as greater numbers of books are recorded. Thus a student who says he read 30 books may indeed have read 20 or 40 ; but a student who says he read 8 books cannot be far off. Most students fell in the humble and more reliable group. sults: (1) Half the students accounted for 86 per cent of the books borrowed; and a third accounted for three quarters of the books borrowed. (2) Generally, students read little or much depending on how much they had to read, not on how much independent reading they did. (3) Generally, independence in reading went unrewarded by grades. (4) About a quarter of the students read over half of every book they borrowed, and only 15 per cent borrowed any books they failed to read at all. These examples are given not so much for their intrinsic worth as to show some points questionnaires can bring out especially well. Other observations were made, and more could be derived from the data.

Despite the flaws which naturally attend a sampling of this kind, the survey showed that the questionnaire with the sample approach is an effective way to examine student library use in universities and colleges of all sizes and kinds. It should make it easier to go beyond bald circulation figures.

The study would be worse than useless if we let ourselves think that numbers can adequately express the subtle relations between students and their library. Still, these numbers will, if kept in proper perspective, prove valuable practical aids in shaping the public services and in weighing locally the merits of departmental and divisional libraries, reserve systems, and undergraduate libraries.

\section{Help Wanted!}

Know of any manuscript collections of Americans who have had dealings with Africa? A preliminary bibliography on Americans who have been involved in Africa south of the Sahara since 1870 , or who have written about that area, is being prepared by Peter Duignan, curator, Africa Collection, The Hoover Institution on War, Revolution, and Peace, Stanford University, Stanford, Calif., and Dr. Robert Collins of Williams College.

Librarians, archivists, or anyone who may know of such manuscript collections, are invited to supply Mr. Duignan with the following information: a short bibliographical sketch of the author; his activities in Africa (when, where and why); and the location of the papers, their size and scope. 